\title{
Functionalization of alumina particles to improve the performance of eco-friendly brake-pads
}

\author{
Vanvirsinh CHAUHAN ${ }^{1}$, Jayashree BIJWE ${ }^{1, *}$, Ashish DARPE ${ }^{2}$ \\ ${ }^{1}$ Centre for Automotive Research and Tribology (formerly ITMMEC), Indian Institute of Technology Delhi, Hauz-Khas, New Delhi-110016, \\ India \\ ${ }^{2}$ Mechanical Engineering Department, Indian Institute of Technology Delhi, Hauz-Khas, New Delhi-110016, India \\ Received: 10 April 2020 / Revised: 20 July 2020 / Accepted: 14 October 2020 \\ (C) The author(s) 2020 .
}

\begin{abstract}
Abrasives, such as oxides of alumina ( $\mathrm{Al})$, silica $(\mathrm{Si})$, zirconia $(\mathrm{Zr})$, chromium $(\mathrm{Cr})$ etc., are added to raise the friction level and also to remove the glaze on the disc so that surface will be rejuvenated continuously during braking and will contribute to maintain the desired friction level. However, these inorganic particles have less adhesion with the resin/binder and hence are easily dug out during wearing process contributing to higher wear. If efforts are made to enhance the filler-matrix adhesion, not only the wear of friction material (FM) should reduce, the particles may stay for a longer time on the tribo-surface of the pads to contribute fully towards controlling the coefficient of friction $(\mu)$. In the present study, alumina particles were selected for siloxane treatment to improve the filler-matrix adhesion. Two types of eco-friendly (free from asbestos and $\mathrm{Cu}$ ) brake-pads were developed using alumina as a theme ingredient (treated and untreated) keeping all the parent formulation identical. An additional type of brake-pads without alumina particles was also developed to observe the effect of abrasive particles on the tribo-performance. The performance properties (physical, mechanical, and tribological) of brake-pads were compared when evaluated in identical conditions. The tribotesting was done on full-scale brake inertia dynamometer following the procedure in Japanese automobile standard (JASO C 406). It was observed that siloxane treatment affected both friction and wear of brake-pads in a beneficial way. Wear resistance got increased 35\% for siloxane treated pads. Worn surfaces were analysed using scanning electron microscopy (SEM) and energy dispersive X-ray (EDAX) technique.
\end{abstract}

Keywords: friction materials; brake-pads; siloxane treatment; friction modifiers; inertia brake-dynamometer

\section{Introduction}

Brake friction materials (FMs) should be designed to achieve a stable friction in desired range (coefficient of friction $(\mu): \sim 0.30$ to 0.45 ) depending on the type of vehicle apart from several diverse demanding performance properties and hence formulation of friction materials (FMs) is one of the most challenging tasks. FMs are complex heterogeneous mixtures of several ingredients, which are classified into four types such as binders, fillers, fibers and friction modifiers [1, 2]. Friction modifier comprises of two types, viz. abrasives and solid lubricants. Abrasive particles control the $\mu$ and remove pyrolized friction film at the interface of a tribo-couple [3-5] while solid lubricants are for lowering the undulations in $\mu$. Commercial brake-pads contain approximately $1-8 \mathrm{vol} \%$ of abrasive particles, such as zirconia, alumina, silica quartz, Zr-silicate etc., and the type, hardness, shape, size and amount of control the final performance apart from their compatibility with resin. These particles are believed to influence noise and vibration (NV) performance since they directly abrade the disc surface and play a key role in the film formation that

* Corresponding author: Jayashree BIJWE, E-mail: jbijwe@gmail.com 
can attenuate friction excitation generated at the interface of a tribo-couple [6-10]. The inappropriate selection of abrasives in the FMs may lead to excessive wear rate, counter face damage, instability in friction level, brake squeal noise etc. [11]. Abrasive particles in general, are oxides of alumina $(\mathrm{Al})$, silica $(\mathrm{Si})$, zirconia $(\mathrm{Zr})$, etc. with less surface energy and hence less adhesion with the resin/binder and hence are easily dug out during wearing process contributing to higher wear. Efforts to increase adhesion of such particles with resin may lead to reduction in wear. It may also affect friction since firmly held particles are expected to contribute to friction more compared to loosely held particles. It may also affect two body or three body abrasion process during wearing of pad.

Chemical modification/siloxane treatment to Prosopis juliflora fibers (PJFs) and scallop shell and periwinkle shell powder improved the thermal stability, shear strength, hardness and also adhesion with the matrix and reduced the wear of composites [12-13]. The mechanical properties such as fracture toughness and pseudo elastic properties of composites with siloxane treated jute fibers got improved significantly [14]. Surface properties of alumina particles treated with various types of siloxane coupling agents were examined by inverse gas chromatography (IGC) and improvement in adhesion with the matrix was reported
[15]. Surface wettability (evaluated by water contact angle method) of silica nanoparticles (NPs) with phenolic resin improved significantly with organo-siloxane compounds [16].

No efforts are, however, placed to examine the effect of treatment to abrasive particles such as alumina in FMs to improve the performance including wear. Hence, in this paper, identical formulations of $\mathrm{Cu}$-free $\mathrm{NAO}$ (non-asbestos organic) FMs containing alumina particles (treated and untreated) were selected to examine the effect of siloxane treated alumina particles on the performance properties of brake-pads. One more type of brake-pads was developed without inclusion of alumina to understand the consequences on the performance properties and results are presented in the subsequent sections.

\section{Materials and methodology}

Details of ingredients selected for developing proposed brake-pads are given in Table 1 along with their details of suppliers.

\subsection{Surface modification of alumina by siloxane treatment}

Alumina particles were sieved and particles of size

Table 1 Details of ingredients used in brake-pads.

\begin{tabular}{lcl}
\hline \multicolumn{1}{c}{ Ingredients } & Size of particle & \\
\hline Parent ingredients & & Origin \\
Straight phenolic resin & $74 \mu \mathrm{m}$ & Allied Nippon Pvt. Ltd., Ghaziabad, India \\
PAN fiber-CFF 110-1 & $D-10 \mu \mathrm{m}$ & Sterling Fibers Inc., USA \\
Aramid Twaron pulp & $L-1.05 \mathrm{~mm}$ & Teijin Aramid, Netherlands \\
Rockwool RB-250 & $L-125 \pm 25 \mu \mathrm{m} ; D-5.5 \mu \mathrm{m}$ & Lapinus Fibers, Netherlands \\
SS swarf (SSS) & $125-250 \mu \mathrm{m}$ & Kasturi Metal Composites (P) Ltd. Amravati, India \\
Natural graphite & $\mathrm{D} 9073.3$ & Starke International Ltd., Delhi, India \\
Vermiculite particles & $100-350 \mu \mathrm{m}$ & Starke International Ltd., Delhi, India \\
CSNL particles & $150 \mu \mathrm{m}$ & Satya Cashew Chemicals, Chennai, India \\
Potassium titanate & $15-25 \mu \mathrm{m}$ & Otsuka Chemicals, Co., Ltd., USA \\
Promaxon-D & $35-85 \mu \mathrm{m}$ & Promat International N.V, Belgium \\
Crumb rubber & $430 \mu \mathrm{m}$ & Local supplier \\
\hline Theme ingredients & & \\
Alumina & $48-100 \mu \mathrm{m}$ & Hindalco Industries, Delhi, India \\
Barite & $10-100 \mu \mathrm{m}$ & Starke International Ltd., Delhi, India \\
\hline
\end{tabular}


range around 50-63 $\mu \mathrm{m}$ were separated. Chemicals used for siloxane treatment are given in Table 2 . Surface modification of alumina $\left(\mathrm{Al}_{2} \mathrm{O}_{3}\right)$ particles with 3-Aminopropyl triethoxty siloxane (APTES) was done using reflux reaction, in xylene as a medium. The temperature was maintained at $100{ }^{\circ} \mathrm{C}$ for 48 hours in a silicon bath keeping molar ratio 1.5 for APTES to $\mathrm{Al}_{2} \mathrm{O}_{3}$. Mechanical stirring was provided so that the particles do not settle down in the solution. The particles were washed with xylene twice and then ethanol followed by acetone and using centrifuge and filtering. The particles were finally dried in an oven at $50^{\circ} \mathrm{C}$.

\subsection{Characterization of particles}

Scanning electron micrographs (SEM) of particles are shown in Fig. 1, indicating platelet shape and average size of $50-63 \mu \mathrm{m}$.

\subsection{Studies on siloxane treated particles}

It was necessary to verify if particles were coated with siloxane after treatment. Hence, Fourier-transfer infrared (FTIR) spectroscopy was employed on the FTIR spectrometer (Thermo Scientific, NICOLET iS50 FT-IR) and the spectra of treated (coded as $A_{p t}$ ) and untreated (coded as $A_{p u}$ ) particles are shown in Fig. 2(a). The stretching vibration of $\mathrm{Al}-\mathrm{O}$ - was observed by a broad band in the region $\approx 730 \mathrm{~cm}^{-1}$ confirming alumina particles. Stretching vibration of $\mathrm{Si}-\mathrm{O}-$ bond was confirmed by the broad band observed at $1,060 \mathrm{~cm}^{-1}$ whereas out-of-plane $\mathrm{Si}-\mathrm{O}$ - stretching for the siloxane group attached to alumina particles was observed for 1,150 $\mathrm{cm}^{-1}$ [17]. Micrographs and EDAX data in the form of Si dot maps in Fig. 2(b) also support siloxane coating. It was confirmed that $\mathrm{Si}$ dot maps were observed where $\mathrm{Al}$ dot maps were highest. This correspondence proved that siloxane treatment was on the particles.

It was necessary to know if the siloxane treatment lasts at higher temperature since brake-pad temperature may rise to excess of $350{ }^{\circ} \mathrm{C}$ during friction. Hence, thermo-gravimetric analysis (TGA) was done on treated alumina $\left(\mathrm{A}_{\mathrm{pt}}\right)$ (LENSEIS, STA PT 1000) sample

Table 2 Details of chemicals used for siloxane treatment.

\begin{tabular}{|c|c|c|}
\hline Chemical property & propyl triethoxy siloxane ( & Alumina \\
\hline Source & Thermo Fisher Scientific & Hindalco Industries, Delhi, India \\
\hline Formula & $\mathrm{C}_{9} \mathrm{H}_{23} \mathrm{NO}_{3} \mathrm{Si}$ & $\mathrm{Al}_{2} \mathrm{O}_{3}$ \\
\hline Formula weight & $221.37 \mathrm{~g} / \mathrm{mol}$ & $101.96 \mathrm{~g} / \mathrm{mol}$ \\
\hline Colour & Colourless & White \\
\hline $\begin{array}{l}\text { Appearance } \\
\text { (form) }\end{array}$ & Liquid & $\begin{array}{c}\text { Solid } \\
\text { (white powder) }\end{array}$ \\
\hline Purity (GC) & $>99.5 \%$ & $>96.5 \%$ \\
\hline True density & $0.946 \mathrm{~g} / \mathrm{mL}$ & $4.02 \mathrm{~g} / \mathrm{cm}^{3}$ \\
\hline
\end{tabular}
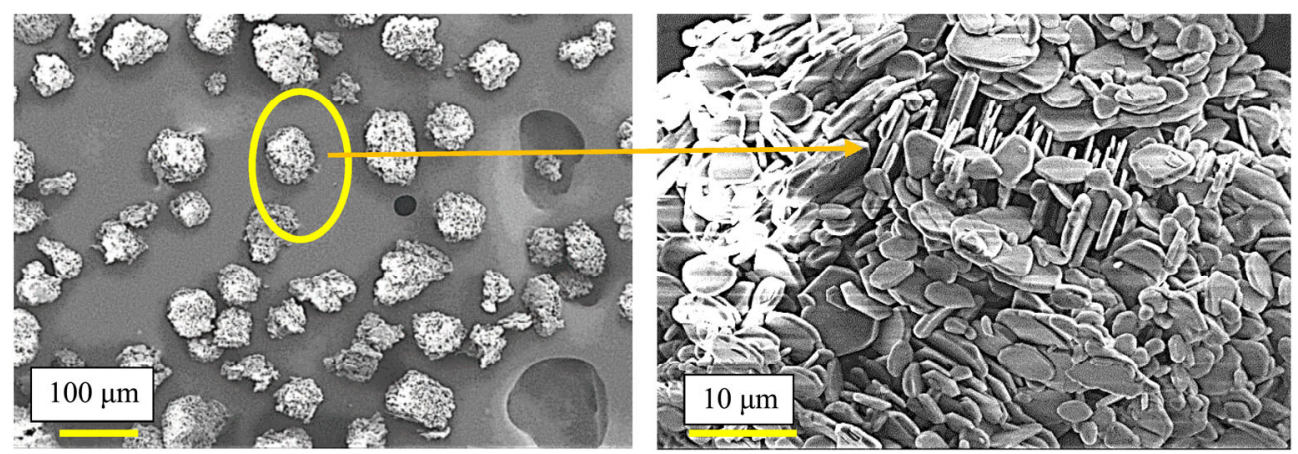

Fig. 1 SEM micrographs of alumina particles. (a) $150 \times$ and (b) $2,000 \times$. 


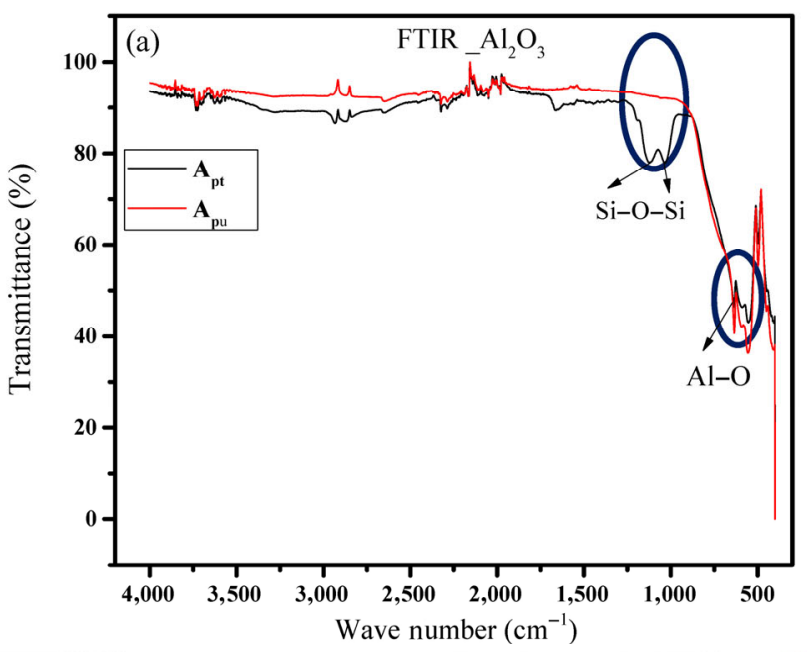

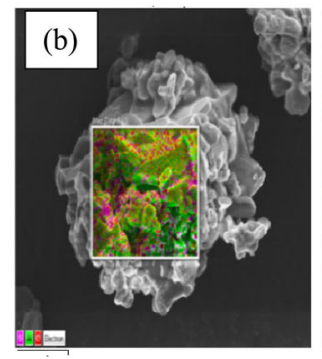

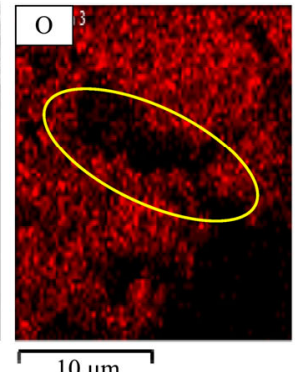

$10 \mu \mathrm{m}$

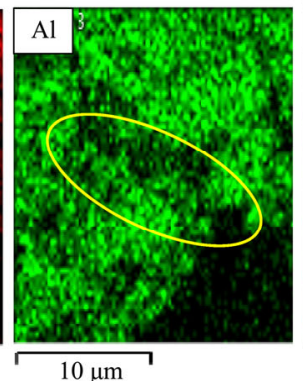

$10 \mu \mathrm{m}$

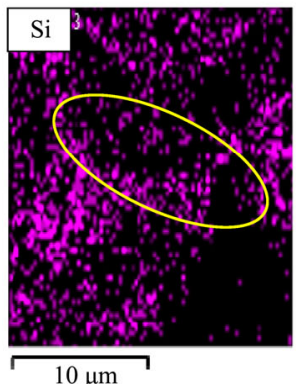

$10 \mu \mathrm{m}$

Fig. 2 (a) FTIR spectra of treated $\left(\mathrm{A}_{\mathrm{pt}}\right)$ and untreated $\left(\mathrm{A}_{\mathrm{pu}}\right) \mathrm{Al}_{2} \mathrm{O}_{3}$ particles and (b) SEM and EDAX micrographs of siloxane treated $\mathrm{Al}_{2} \mathrm{O}_{3}$ particles confirming presence of $\mathrm{Si}$ due to treatment (yellow-marked area shows that alumina particles and hence siloxane coating were absent).

(scanning rate $10{ }^{\circ} \mathrm{C}$ per minute) and results are shown in Fig. 3. It was confirmed that a slight degradation in siloxane started at $350{ }^{\circ} \mathrm{C}$ and only $7.5 \%$ of material loss was observed till $750{ }^{\circ} \mathrm{C}$, out of which $1.25 \%$ was due to moisture at $100{ }^{\circ} \mathrm{C}$. TGA of untreated alumina was not done since it is known for its thermal stability and is also used as reference material in TGA.

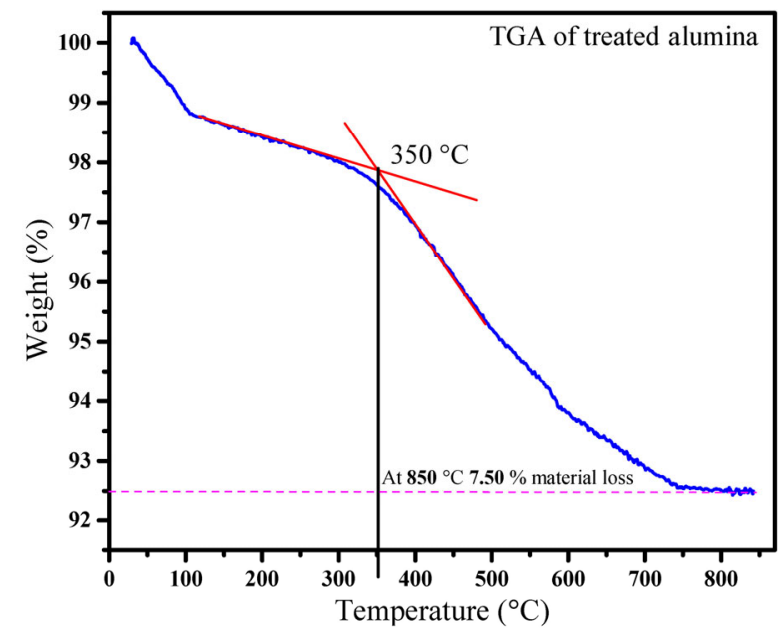

Fig. 3 TGA data on siloxane treated $\mathrm{Al}_{2} \mathrm{O}_{3}$ particles.

\subsection{Design and development of brake-pads}

Three different types of brake-pads were prepared by keeping $76 \mathrm{wt} \%$ of eleven ingredients identical as a parent composition, comprising of four core classes of ingredients viz. binder- $6 \mathrm{wt} \%$, friction modifiers (solid lubricant)-10 wt\%, fibers (Twaron pulp, PAN, rockwool)-16 wt $\%$, functional fillers (potassium titanate, vermiculite, CSNL powder, Promaxon-D, crumb rubber, SS swarf)-44 wt $\%$. Remaining $24 w t \%$ was filled with the theme ingredients, out of which alumina abrasive particles were $2 \mathrm{wt} \%$ (Table 3). One more type of brake-pad was formulated without alumina particles and increasing barite, inert filler by $2 \%$. The brake-pads were developed as per procedure reported in the earlier literature [18, 19]. Homogeneous mixture (around $65 \mathrm{~g}$ ) was cold pressed in the form of Alto ${ }^{\mathrm{TM}}$ Car brake-pads and kept in oven $\approx 70-80{ }^{\circ} \mathrm{C}$ for 30 minutes to remove moisture to avoid cracks during hot compression moulding. These were then hot moulded in the hydraulic compression moulding machine at 140 bar pressure and $160-165^{\circ} \mathrm{C}$ for nine 
Table 3 Designations of developed brake-pads with formulations.

\begin{tabular}{cccc}
\hline & \multicolumn{3}{c}{ Designations of brake-pads } \\
\cline { 2 - 4 } Ingredients by wt $\%$ & $\mathrm{~A}_{0}$ & $\mathrm{~A}_{\mathrm{u}}$ & $\mathrm{A}_{\mathrm{t}}$ \\
Parent composition & 76 & 76 & 76 \\
Alumina $\left(\mathrm{Al}_{2} \mathrm{O}_{3}\right)$ & - & 2 & 2 \\
Barite & 24 & 22 & (untreated) \\
\hline
\end{tabular}

* Parent composition — binder: friction modifiers: fibers: functional fillers-6:10:16:44;

Subscripts 't' and ' $u$ ' denote alumina particles-siloxane treated and untreated, while 0 indicates brake-pad without alumina particles.

minutes. Five to six intermediate breathings were given to allow the volatiles to escape from cavity. Post-curing of brake-pads was done in an oven at 120 and $160{ }^{\circ} \mathrm{C}$ for 2 and $5 \mathrm{hrs}$, respectively. Grinding and finishing was done for achieving desired thickness and surface finish.

\subsection{Characterization of brake-pads}

Before tribological evaluation on full-scale brake inertia dynamometer, brake-pads were characterized for physical (density, water porosity and oil porosity), mechanical (hardness, compressibility and shear strength) and chemical (acetone extraction) properties as per standard procedure as reported elsewhere [18, 19]. Thermal conductivity of brake-pads was measured on thermal analyser (Linseis, LFA 500) at ambient temperature.

\subsection{Tribo-evaluation of brake-pads}

Tribo-performance of brake-pads was evaluated on full scale inertia brake inertia dynamometer to measure frictional torque and other output parameters. The schematic diagram, specifications and detailed description of brake inertia dynamometer have been reported in our previous work [18-20]. For triboevaluation of developed brake-pads, Japanese Automobile Standard (JASO C 406) schedule (Appendix B) was used. The details of whole tribo-evolution test schedule reported sequentially as per JASO C 406 reported elsewhere [19]. Every time new set of disc and brake-pads were used. Every test was repeated once and average value was reported.

\subsection{Worn surface analysis}

\subsubsection{SEM and EDAX analysis}

Worn surface analysis was done by using SEM (ZEISS EVO-MA10) and EDAX (Bruker AXS $127 \mathrm{eV}$ ).

\subsubsection{Contact angle measurement}

Contact angles on the discs and brake-pads were measured using a Goniometer (Kruss GmbH DSA25S) by Sessile drop method using $0.512 \mathrm{~mm}$ diameter syringe and $2 \mu \mathrm{L}$ of deionised (DI) water with automatic dozer. Average of five values of contact angles was considered.

\section{Results and discussion}

\subsection{Characterization of brake-pads}

Table 4 shows the data on physical, mechanical and chemical characterization of brake-pads along with arrows showing increasing or decreasing trends. The density of pads increased marginally; first due to addition of alumina particles and then due to siloxane treated alumina particles as a result of increased adhesion with resin. Uncured resin percentage, was quite low. Porosity and compressibility results, however, did not show a strict correlation. Hardness, shear

Table 4 Physical, chemical, and mechanical characterization results.

\begin{tabular}{|c|c|c|c|}
\hline \multirow[t]{2}{*}{ Properties } & \multicolumn{3}{|c|}{ Designations of brake-pads } \\
\hline & $\mathrm{A}_{0}$ & $\mathrm{~A}_{\mathrm{u}}$ & $A_{t}$ \\
\hline Density (g/cc) SAE J 380 & 1.98 & 2.03 & 2.11 \\
\hline $\begin{array}{c}\text { Water porosity (\%) JIS D } \\
\text { 4418:1996 }\end{array}$ & 11.25 & 10.69 & 13.61 \\
\hline $\begin{array}{c}\text { Oil porosity (\%) JIS D } \\
\text { 4418:1996 }\end{array}$ & 8.76 & 11.32 & 10.10 \\
\hline $\begin{array}{l}\text { Acetone extraction (\%) } \\
\text { ASTM D } 494\end{array}$ & 0.462 & 0.319 & 0.175 \\
\hline $\begin{array}{c}\text { Shear strength }\left(\mathrm{kg} / \mathrm{cm}^{2}\right) \\
\text { ISO } 6312\end{array}$ & 38.42 & 42.79 & 44.97 \\
\hline $\begin{array}{c}\text { Compressibility (micron) } \\
\text { ISO } 6310\end{array}$ & 61 & 71 & 66 \\
\hline $\begin{array}{l}\text { Hardness (HRR) } \\
\text { ASTM D } 785\end{array}$ & 89.7 & 97.2 & 99.5 \\
\hline $\begin{array}{c}\text { Thermal conductivity }(\mathrm{W} /(\mathrm{m} \cdot \mathrm{K})) \\
\text { ASTM E1461-01 }\end{array}$ & 1.2 & 1.246 & 1.298 \\
\hline
\end{tabular}


strength and thermal conductivity (TC) showed increasing trend, which may influence fade and wear performance.

\subsection{Tribo-evaluation of brake-pads}

Two cycles viz. effectiveness and fade and recovery were carried out as per JASO C 406 standard and results are presented here.

\subsubsection{Effectiveness cycle}

Effectiveness parameter is indicative of influence of speed and deceleration on friction performance. To prevent the interference of temperature effect, during breaking the temperature of disc was kept constant at $80{ }^{\circ} \mathrm{C}$, till next cycle started. Figure 4 shows the variation of $\mu$ with the deceleration. Three different types of fade like pressure-fade, speed-fade, and temperature-fade were observed during tribo-testing of brake-pads and the related data generated in this cycle are shown in Figs. 4-7. Figure 4 shows the variation in pressure from 0.1 to $0.8 \mathrm{~g}$ at 50,80 , and $100 \mathrm{kmph}$. If the curves are observed horizontally, they are indicative of pressure fade at each speed. If they are observed vertically at each " $\mathrm{g}$ " value (marked a few spots), they indicate speed fade.

As seen from Fig. 4 for all speeds $A_{t}$ (treated alumina) had highest $\mu$ and lowest undulations (pressure fade) among all. The performance order from pressure fade point of view was; $A_{t}>A_{u}>A_{0}$. Hence, pressure

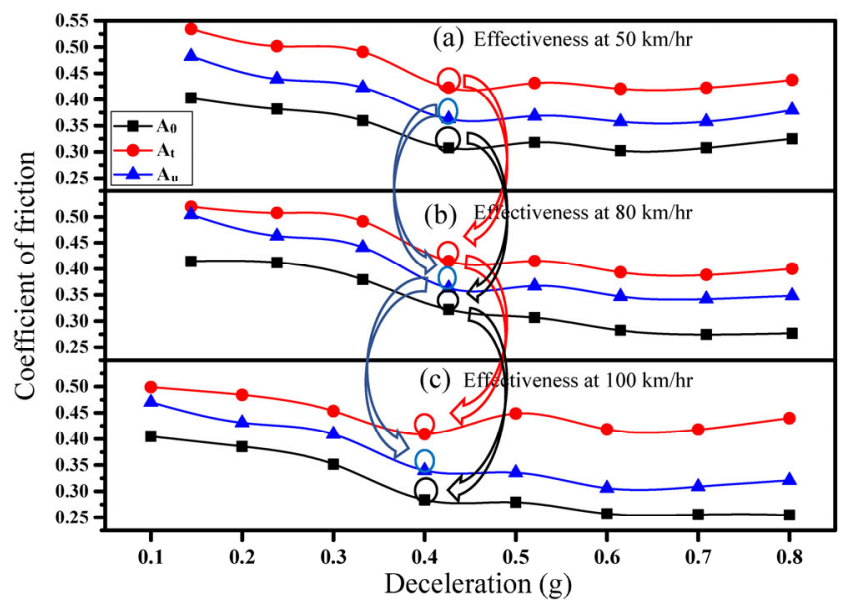

Fig. $4 \mu$ as a function of deceleration at various speeds: (a) 50, (b) 80, and (c) $100 \mathrm{kmph}$ (horizontal-pressure fade; verticalspeed fade; typical colored markings indicate selected pads: red arrows for $A_{t}$; blue arrows- $A_{u}$, and black arrows $A_{0}$ ). fade resistance increased due to siloxane treatment in the pads. Ideally, the curves should not be slanting. In case of polymers and composites, however, $\mu$ generally decreases with increase in pressure because of viscoelastic nature of pad material. The extent of decrease, however, should be as small as possible.

As seen from Fig. 4 following are the observations:

1) The $\mu$ was lowest for pad without alumina particles $\left(\mathrm{A}_{0}\right)$ as expected since these particles function as abrasive filler. The highest $\mu$ was shown by $A_{t}$, which could be because the particles were held more firmly by matrix and contributing to the friction to the fullest capacity. If these are loosely bound, they are easily dug out contributing to higher wear and lower friction since this friction is mostly three body abrasive one as in case of $A_{u}$ while for $A_{t}$ it was mostly two body abrasive wear;

2) The most obvious trend in $\mu$ vs deceleration was about the decline in $\mu$ right from beginning for $\mathrm{A}_{0}$ and $A_{u}$ which is not a beneficial feature. In case of $A_{t}$ however, the trend was excellent especially at highest speed (100 kmph);

3) With increase in speed magnitude of $\mu$ for each pad decreased at same pressure, but at different extents as marked in the Fig. 4, which is called speed-fade. This trend was calculated in term of speed spread and presented in subsequent figures.

\subsubsection{Average $\mu$, fluctuations in $\mu(\Delta \mu)$ and sensitivity of $\mu$ to the speed}

Average $\mu$ of pads in effectiveness cycle is shown in Fig. 5, while extent of fluctuations in $\mu(\Delta \mu)$ are shown in Fig. 6. Sensitivity $\mu$ to speed is shown in Fig. 7. Both the $\Delta \mu$ and sensitivity $\mu$ to the speed, pressure, and temperature should be as small as possible. As seen in Fig. 5, inclusion of alumina has resulted increase in $\mu$ around $18 \%-19 \%$ compare to $A_{0}$. Compared to the untreated particles in $\mathrm{A}_{\mathrm{u}}$ siloxane treated particles in $\mathrm{A}_{\mathrm{t}}$ led to a further increase (around 15\%-22\%) in $\mu$ confirming beneficial effect of siloxane treatment on alumina particles. Performance order from average $\mu$ point of view was; $A_{t}>A_{u}>A_{0}$. The reason has already explained in earlier discussion.

\subsubsection{Friction stability}

Figure 6 shows the $\Delta \mu$ in effectiveness cycle for three 


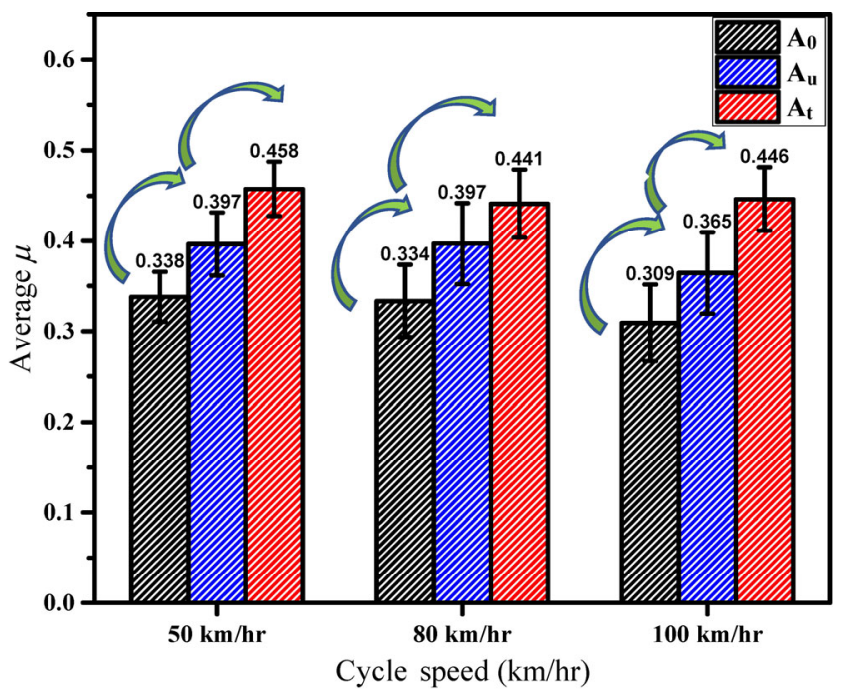

Fig. 5 Average $\mu$ of brake-pads at 50, 80, and $100 \mathrm{kmph}$.

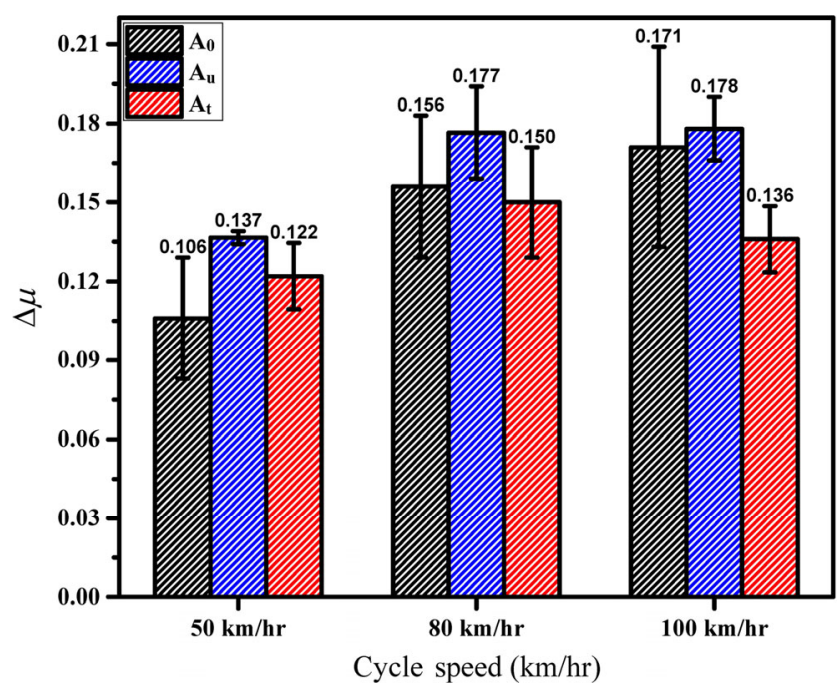

Fig. 6 Fluctuations in coefficient of friction $(\Delta \mu)$ at 50,80 , and $100 \mathrm{kmph}$.

speeds. Ideally $\Delta \mu\left(\mu_{\max }-\mu_{\min }\right)$ should be as small as possible. Inclusion of abrasive particles was expected to result in fluctuations in $\mu$. In spite of this, except at low speed $(50 \mathrm{kmph})$ siloxane treated brake pads $\left(\mathrm{A}_{\mathrm{t}}\right)$ showed lowest $\Delta \mu$ among all confirming advantages of siloxane treatment.

\subsubsection{Performance in the form of $\%$ speed-spread}

$\%$ speed-spread (\% SS) in effectiveness test is a ratio of a $\mu$ at a higher speed to $\mu$ at a lower speed and is expressed in terms of percentage. Thumb rule indicates; higher the \% SS, better is the performance rating of brake-pads. Ideally, slope and undulations in the curve should be minimal. Figure 7 shows \% speed-spread

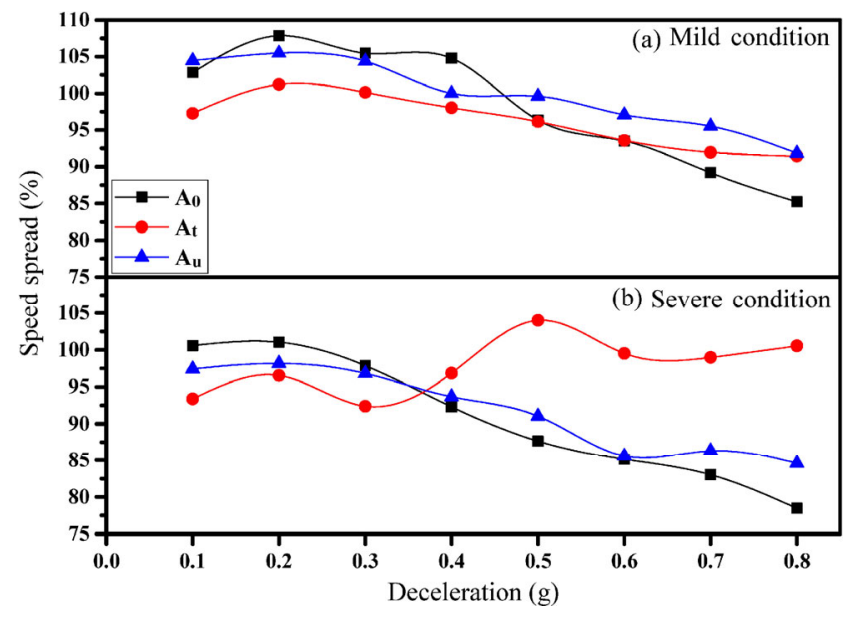

Fig. $7 \%$ SS performance of brake-pads with increasing deceleration: (a) mild condition and (b) severe condition

characteristics of brake-pads for mild and severe speed transitions as a function of deceleration. Overall $\mu$-speed sensitivity was higher in severe condition, which is as per general trends [19].

In mild condition $\mathrm{A}_{\mathrm{u}}$ showed higher average \% SS and minimal undulations compared to $\mathrm{A}_{0}$ and $\mathrm{A}_{\mathrm{t}}$. In case of $\mathrm{A}_{0}, \% \mathrm{SS}$ was higher up to $0.4 \mathrm{~g}$ than it reduced drastically, where in case of $A_{t} \%$ SS was observed almost constant with least undulations. Severe speed transitions were reported in Fig. 7(b), $A_{t}$ showed overall best performance with minimal undulation among all and higher average \% SS particularly in extreme conations.

The performance order speed sensitivity of $\mu$ was,

1) Mild condition (transition from 80 to $50 \mathrm{kmph}$ ): $\mathrm{A}_{\mathrm{u}}>\mathrm{A}_{0}>\mathrm{A}_{\mathrm{t}}$;

2) Severe condition (transition from 100 to $50 \mathrm{kmph}$ ): $\mathrm{A}_{\mathrm{t}}>\mathrm{A}_{\mathrm{u}}>\mathrm{A}_{0}$.

\subsubsection{Fade and recovery $(F \& R)$ cycles}

At elevated temperatures typically above $350-400{ }^{\circ} \mathrm{C}$, a loss in $\mu$ was observed and is referred as temperature fade and after cooling down of brake-pads, extent of revival of $\mu$ to its original position is referred to as recovery. The data on F\&R cycles indicate sensitivity of $\mu$ to temperature and are presented in Figs. 8-12. Sensitivity of $\mu$ to operating parameters should be as small as possible. Ideally fade $\mu$ and recovery $\mu$ should be as high as possible and as close to each other as possible. Figures 8 and 9 show the variation in friction performance during F\&R cycles I and II. Minimum value of $\mu$ was indicated by highlighted portion in 


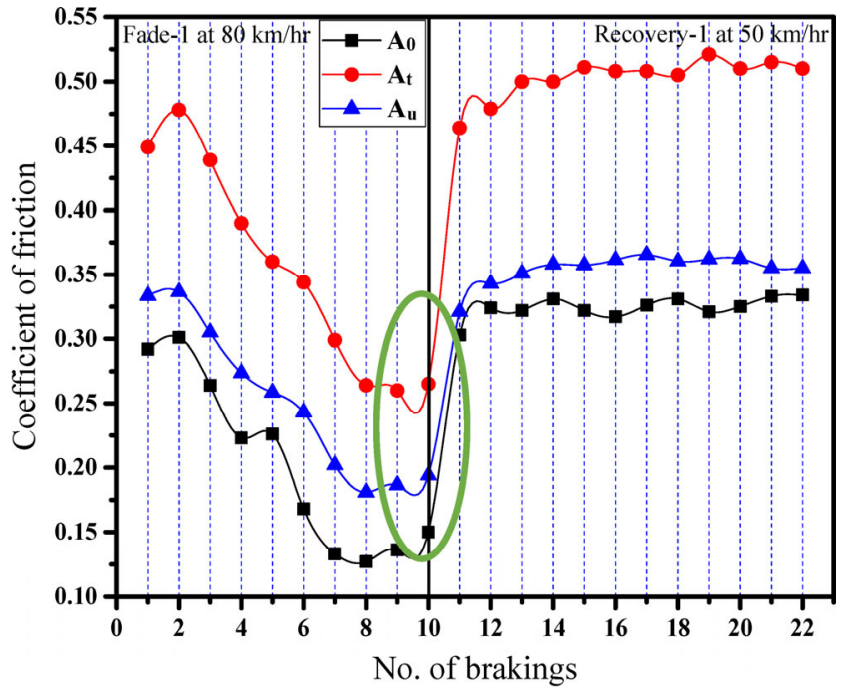

Fig. 8 Variation in coefficient of friction for fade and recovery cycle-I (green highlight indicate minimum $\mu$ in the fade cycle).

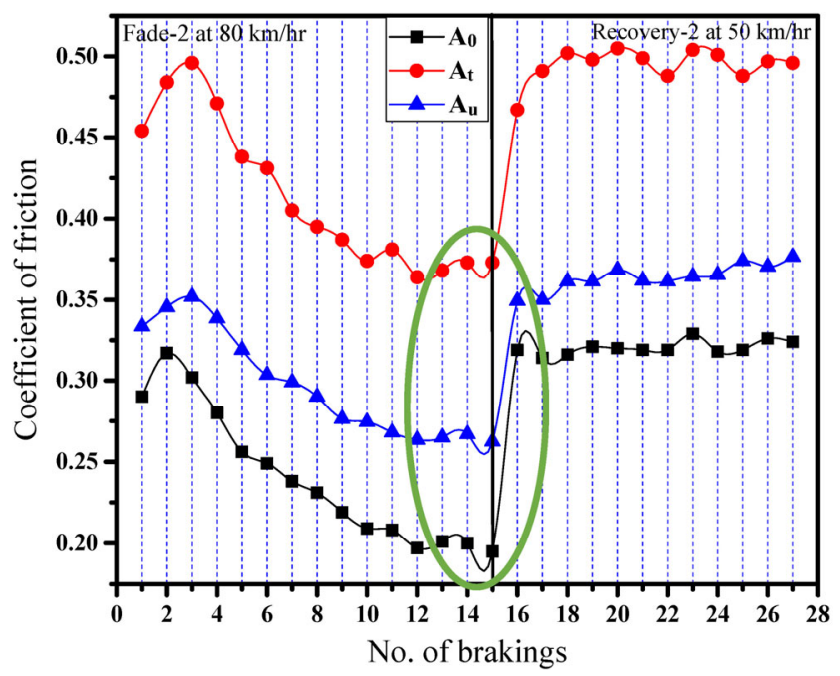

Fig. 9 Variation of coefficient of friction for fade and recovery cycle-II (green marks indicate transition in $\mu$ from fade cycle to recovery cycle).

Figs. 8 and 9 during fade cycle I and II respectively. During F\&R cycle-I, 1-10 cycles were considered as temperature-fade and 11-22 cycles were considered for Recovery (Fig. 8). During F\&R cycle-II, 1-15 cycles were considered as temperature-fade and 16-27 cycles were considered for Recovery (Fig. 9). The performance order from temperature fade and recovery point of view was; $A_{t}>A_{u}>A_{0}$. $A_{t}$ reported highest $\mu$ in both F\&R cycles.

\subsubsection{Average fade and recovery $\mu$ for $F \& R$ cycles}

Figure 10 comprises of the data on average $\mu$ for $F \& R$

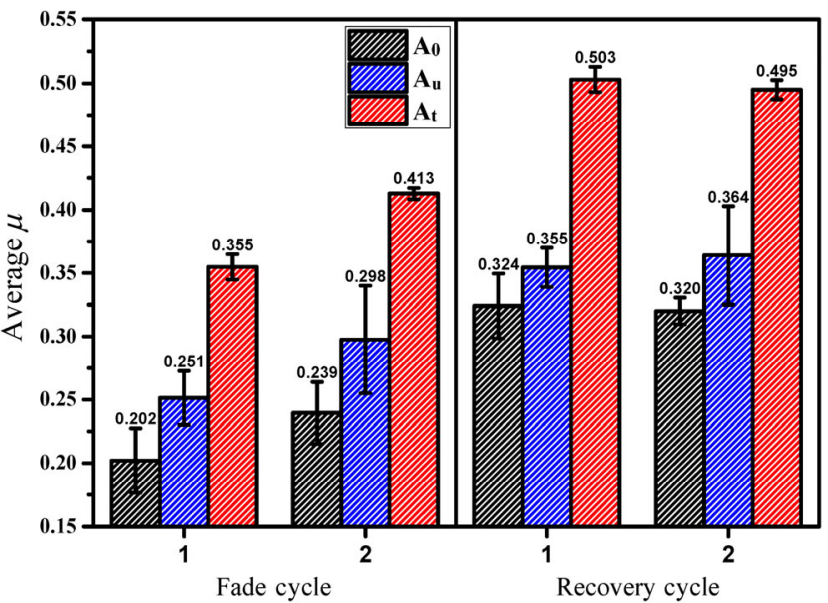

Fig. 10 Average fade and recovery $\mu$ for F\&R cycles I and II (left column: fade cycle I-II, right column: recovery cycle I-II).

cycles confirming significant benefits of inclusion of alumina particles and siloxane treatment.

\subsubsection{Fade and recovery performance}

Figure 11 shows \% fade ratio and \% recovery ratio. It is a ratio of minimum to maximum $\mu$ in percentage with increase in temperature during fade cycle I-II and recovery cycle I-II. Ideally these ratios should be higher. The major observation was about inclusion of alumina particles increased the performance in fade cycles significantly but deteriorated marginally in recovery cycles. Siloxane treatment proved beneficial in this aspect also though not significantly.

\subsubsection{Maximum disc temperature rise (lower the better)}

Figure 12 shows the rise in temperature of the discs,

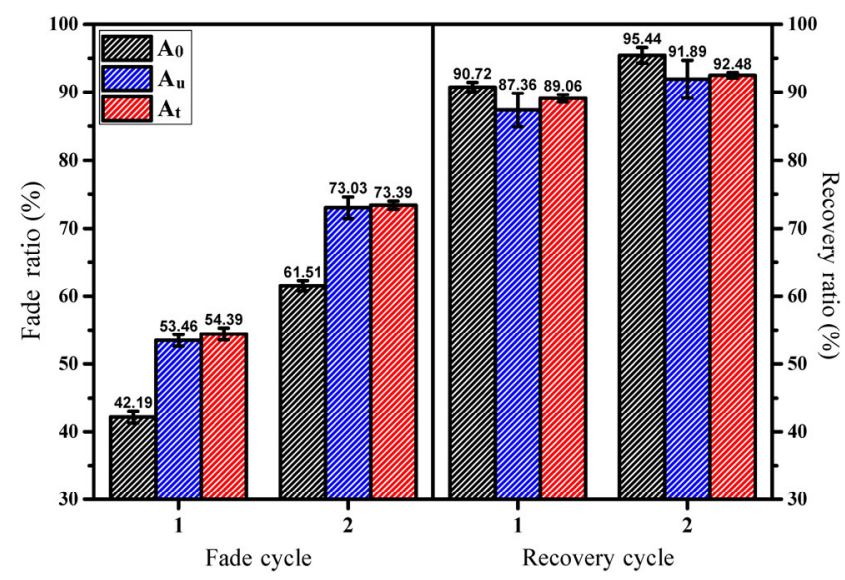

Fig. $11 \%$ fade ratio and \% recovery ratio for F\&R cycles I and II. 


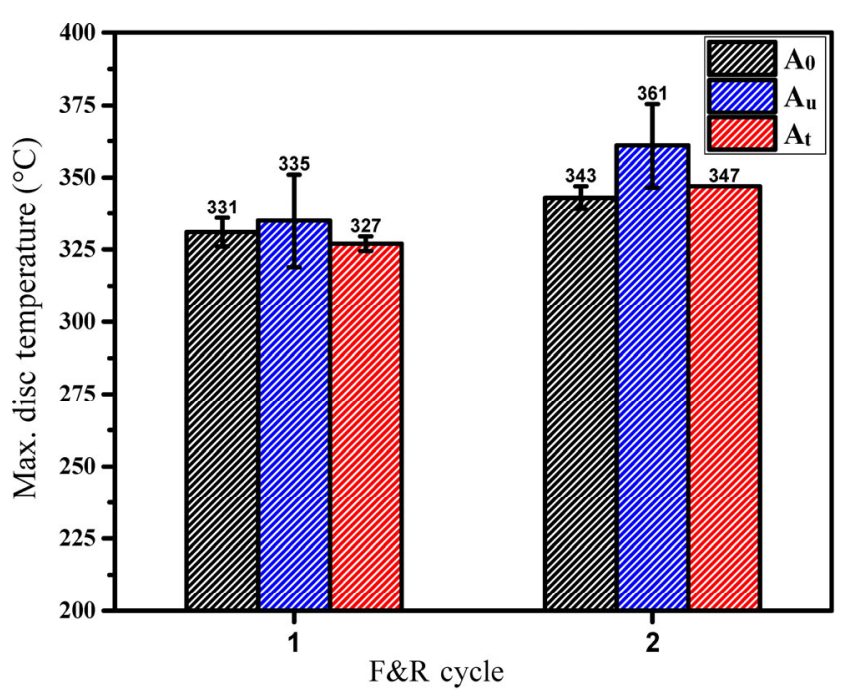

Fig. 12 Maximum disc temperature $\left({ }^{\circ} \mathrm{C}\right)$ during $\mathrm{F} \& \mathrm{R}$ cycles I and II.

which should be as small as possible. One of the major factors responsible for the rise in disc temperature is $\mu$ itself. Higher the $\mu$, higher will be the frictional heat generation and rise in the temperature of the disc. Frictional heat generation is expressed by the equation $Q=(\rho v \mu w) / J$, where $\rho$ is density, $v$ is velocity, $\mu$ is coefficient of friction, $w$ is applied load, and $J$ is mechanical equivalent heat. Other factors such as thermal conductivity (TC), thermal diffusivity (TD) of the disc and brake-pads, heat dissipation rate, ambient temperature, etc. also affect this performance factor. Siloxane treatment indicated significant benefits in this case also in spite of its $\mu$ being highest. It could be possibly due to higher TC of $A_{t}$ compared to $A_{u}$ as reported in the Table 4.

\subsection{Studies on wear of brake-pads}

Figure 13 shows the wear behaviour by both, weight loss and volume loss data. Siloxane treatment led to a substantial decrease (14\%) in weight loss and 35\% in volume loss due to increase in adhesion of alumina particles with the resin. It is a significant improvement in wear performance. The research work had the primary theme to reduce wear of pads containing abrasive particles such as alumina. As seen in Fig. 13, inclusion of alumina increased the wear by $53 \%$. This had to be controlled. Siloxane treated pads showed drastic reduction in wear to the extent that it matched with that of pads without alumina particles.

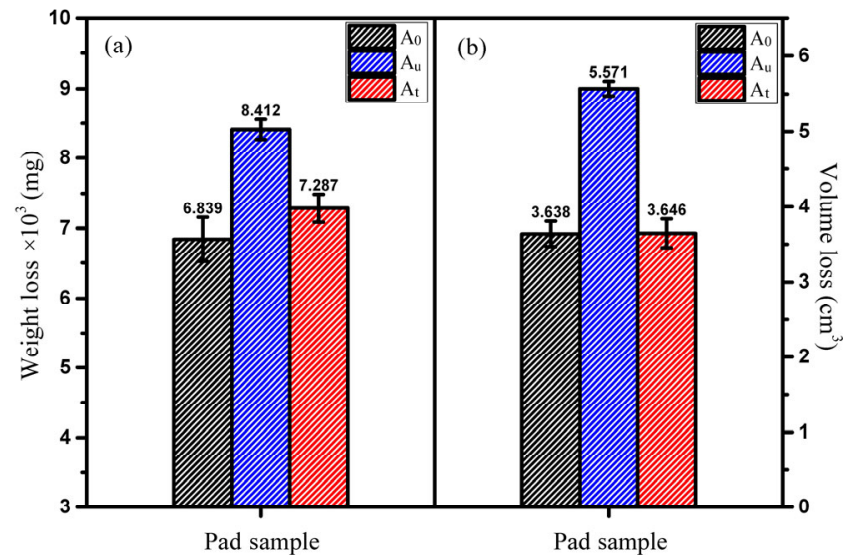

Fig. 13 Wear behaviour of brake-pads by loss in (a) weight and (b) volume.

\subsection{Analysis of worn surfaces}

Worn surface analysis was done by studying contact angles by goniometry and SEM-EDAX.

\subsubsection{Contact angle measurement}

The FMs contain organic ingredients (resin, CSNL powder, and aramid fibers, etc.) which may undergo degradation or thermal deterioration after multiple brakings. Organic polymeric contents indicate low wettability with water or metallic parts or hydrophilicity. It was expected that the worn disc if covered with carbonaceous material (film transfer) would show higher contact angle (low wettability). Brake-pads after wearing would show lower contact angle because of thermal degradation of organic contents and back transfer of metallic debris from the disc. Contact angle measurement of virgin and worn surfaces of brake disc and brake pads were measured and reported in Table 5 using goniometer (details are given in Appendix C). Increase in hydrophobicity due to film transfer on the disc is clearly supported by the increase in contact angle from $106.5^{\circ}$ to approx. $114^{\circ}$. Compared to virgin pads, worn pads showed significant increase in hydrophilicity because of degradation of resin and back-transfer of metallic wear debris. In case of worn pads, hydrophilicity was in the order; $A_{t}>A_{u}>A_{0}$., although the difference was marginal. This was exactly in the order of coefficient of friction.

\subsubsection{Worn surface analysis by SEM-EDAX}

SEM and EDAX micrographs of worn surfaces of the pads along with EDAX data are shown in Fig. 14. It 
Table 5 Goniometer contact angles on worn surfaces of discs and pads against a water drop.

\begin{tabular}{|c|c|c|c|c|}
\hline \multirow{2}{*}{ Brake pad } & \multicolumn{2}{|c|}{ Brake disc contact angle } & \multicolumn{2}{|c|}{ Brake pads contact angle } \\
\hline & Worn surface & Virgin surface & Worn surface & Virgin surface \\
\hline $\mathrm{A}_{0}$ & $111.5^{\circ}$ & 7 & $48.6^{\circ}$ & $116.9^{\circ}$ \\
\hline $\mathrm{A}_{\mathrm{u}}$ & $112.4^{\circ}$ & $-106.5^{\circ}$ & $46.8^{\circ}$ & $104.6^{\circ}$ \\
\hline$A_{t}$ & $113.5^{\circ}$ & & $36.8^{\circ}$ & $106.5^{\circ}$ \\
\hline
\end{tabular}
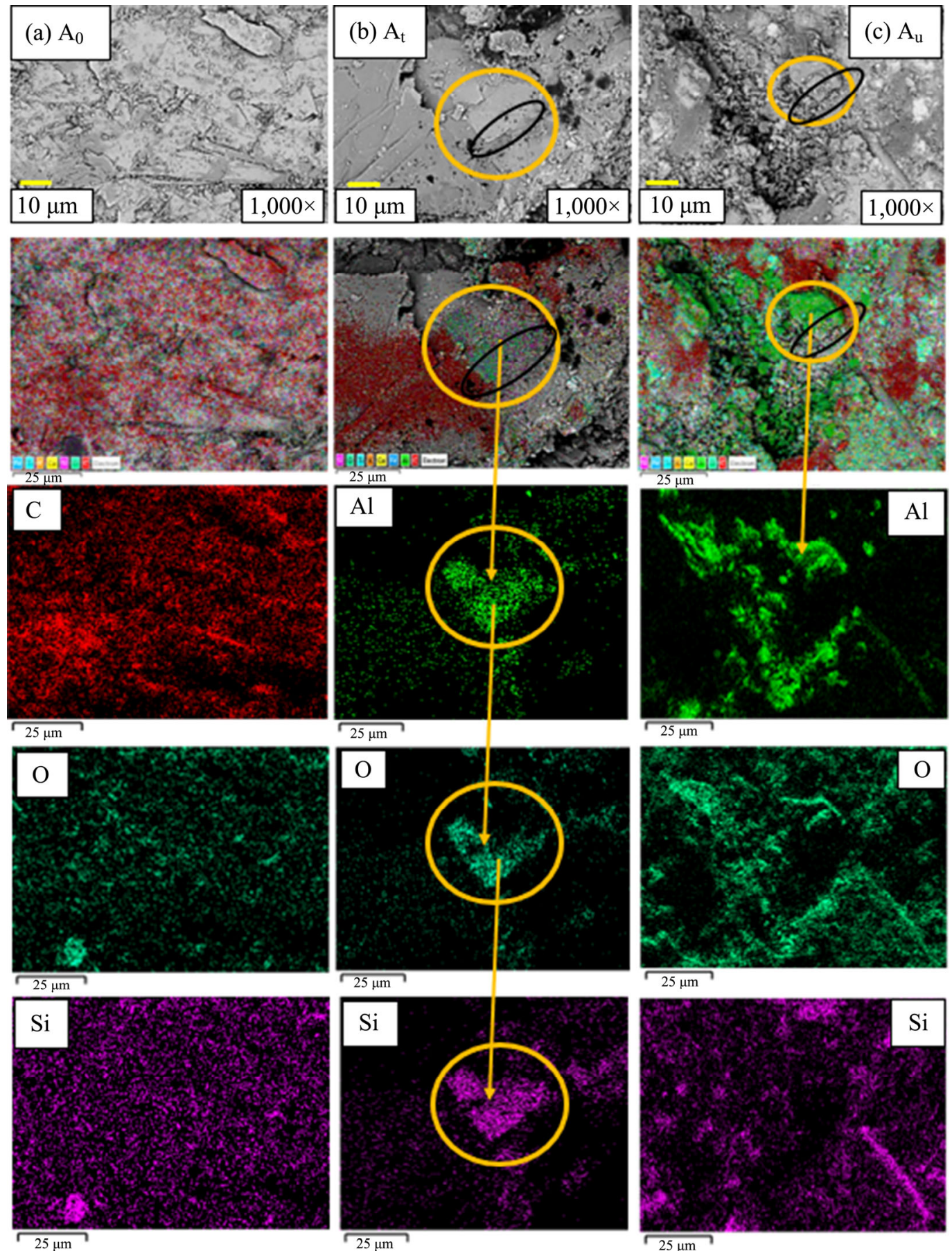

Fig. 14 SEM micrographs and EDAX dot maps of worn surfaces of pads $A_{0}$ (extreme left column), $A_{t}$ (middle column) and $A_{u}$ (extreme right column) at $1,000 \times$. 
was interesting to investigate about the bonding of remaining alumina particles with the matrix after wear test. Micrographs of $\mathrm{A}_{0}$ are also added to understand general distribution of fillers in the pads. Si dot mapping was done to confirm if alumina particles in $A_{t}$ show the evidence of siloxane treatment. The important findings from the micrographs are as follows:

1) If the micrographs Figs. 14(a)-14(c) are compared, topography of Fig. 14(c) is poorest showing lot of deep cracks, back transferred wear debris and secondary plateaus, supporting its poor wear performance. Other two surfaces showed similar topography, which supported their similar wear performance;

2) The alumina particles in $A_{t}$ and $A_{u}$ could be confirmed from EDAX data (dot maps of $\mathrm{Al}$ and $\mathrm{O}$ ) (Figs. 14(b) and 14(c)). Few particles are marked by circles. The black marking shows the interface (particlematrix). It could be clearly seen that the bonding is significantly stronger in $A_{t}$ compared to that in $A_{u}$ which was the reason for higher wear resistance of $A_{t}$;

3) Siloxane treatment on alumina particles was confirmed by the Si dot density in EDAX micrograph of Fig. 14(b). Si dots (dispersed) in other two micrographs are due to other Si-containing constituents such as Promaxon-D, Rock-wool fiber and vermiculite. Promaxon-D, which is a synthetic hydrated calcium silicate with a chemical structure similar to the mineral Xonotlite $\mathrm{Ca}_{6} \mathrm{Si}_{6} \mathrm{O}_{17}(\mathrm{OH})$.

\section{Conclusions}

Inclusion of particles of abrasives in brake-pads is essential from friction point of view. However, it leads to increase in wear. The theme of the work was to increase the adhesion of alumina particles with the matrix by siloxane treatment, which could improve the wear performance. Based on the studies (as summarized in tabular form under the heading-Essence of studies) on three types of pads (first with untreated particles $\mathrm{A}_{\mathrm{u}}$, second with treated particles- $\mathrm{A}_{\mathrm{t}}$ and third without particles- $A_{0}$ ), it was concluded that the treatment not only improved adhesion of particles with the resin and subsequently wear performance significantly, but also all parameters related to friction as follows.

Overall performance ranking based on tribological testing on full-scale brake-inertia dynamometer was, $A_{t}>A_{u}>A_{0}$ confirming the success of siloxane treatment to alumina particles.

Essence of the studies.

\begin{tabular}{|c|c|c|c|c|c|}
\hline Tribo-properties & $\mathrm{A}_{0}$ & $\mathrm{~A}_{\mathrm{u}}$ & $A_{t}$ & $\begin{array}{c}\% \text { improvement due to inclusion } \\
\text { of alumina particles- } \\
\text { (comparison with } \mathrm{A}_{\mathrm{u}}-\mathrm{A}_{0} \text { ) }\end{array}$ & $\begin{array}{l}\text { \% improvement due to Siloxane } \\
\text { treatment on alumina particles } \\
\left(\text { comparison with } \mathrm{A}_{\mathrm{u}}-\mathrm{A}_{\mathrm{t}}\right)\end{array}$ \\
\hline $\begin{array}{c}\text { Average } \mu \\
\text { (higher is better) }\end{array}$ & 0.327 & 0.386 & 0.448 & 18.04 & 16.06 \\
\hline $\begin{array}{c}\Delta \mu \\
\text { (lower is better) }\end{array}$ & 0.144 & 0.162 & 0.136 & -12.5 & 16.05 \\
\hline $\begin{array}{c}\text { Fade } \mu \\
\text { (higher is better) }\end{array}$ & 0.127 & 0.181 & 0.260 & 42.52 & 43.65 \\
\hline $\begin{array}{l}\text { Average fade } \mu \\
\text { (higher is better) }\end{array}$ & 0.202 & 0.251 & 0.355 & 24.26 & 41.34 \\
\hline $\begin{array}{l}\text { Fade ratio }(\%) \\
\text { (higher is better) }\end{array}$ & 42.19 & 53.46 & 54.39 & 26.71 & 1.74 \\
\hline $\begin{array}{c}\text { Recovery } \mu \\
\text { (higher is better) }\end{array}$ & 0.334 & 0.367 & 0.521 & 9.88 & 41.96 \\
\hline $\begin{array}{l}\text { Average recovery } \mu \\
\text { (higher is better) }\end{array}$ & 0.324 & 0.355 & 0.503 & 9.57 & 41.69 \\
\hline $\begin{array}{l}\text { Recovery ratio (\%) } \\
\text { (higher is better) }\end{array}$ & 90.72 & 87.36 & 89.06 & -3.70 & 1.95 \\
\hline $\begin{array}{c}\text { Wear }\left(\mathrm{cm}^{3}\right) \\
\text { (lower is better) }\end{array}$ & 3.638 & 5.571 & 3.646 & -53.13 & 34.55 \\
\hline
\end{tabular}

Note: Negative sign indicates \% decrement. 


\section{Acknowledgements}

Authors are thankful to Mr. Navdeep Bajaj (Project staff I.I.T. Delhi) for helping in siloxane treatment. Authors are also thankful to Mr. Raj Khanolkar (Technical Director, MASU Brakes Pvt. Ltd., Haryana, India) for characterisation of pads (hardness, compressibility, and shear strength).

\section{Appendix A}

1) Fade $\mu$ : Minimum value of coefficient of friction $(\mu)$ during the fade cycle- 1 and 2. (Higher is the better)

2) Fade ratio (\%): $\left(\mu_{\min } / \mu_{\max }\right) \times 100$ (Higher is the better)

3) Recovery $\mu$ : Maximum value of coefficient of friction $(\mu)$ during the recovery cycle- 1 and 2 . (Higher is the better)

4) Recovery ratio (\%): $\left(\mu_{\min } / \mu_{\max }\right) \times 100$ (Higher is the better)

5 ) \% speed-spread (\% SS): ( $\mu_{\text {avg }}$ at higher speed/ $\mu_{\text {avg }}$ at lower speed) $\times 100$. (Higher is the better)

6) $\Delta \mu: \mu_{\max }-\mu_{\min }$ (Lower is the better)

\section{Appendix B}

Table A1 JASO C-406 schedule for testing on the brake inertia dynamometer.

\begin{tabular}{|c|c|c|c|c|c|}
\hline Description & $\begin{array}{c}\text { Speed } \\
(\mathrm{kmph})\end{array}$ & $\begin{array}{l}\text { Decele- } \\
\text { ration }(\mathrm{g})\end{array}$ & $\begin{array}{c}\text { Initial } \\
\text { temperture } \\
\left({ }^{\circ} \mathrm{C}\right)\end{array}$ & $\begin{array}{c}\text { Air } \\
\text { bower } \\
\text { condition a }\end{array}$ & $\begin{array}{l}\text { No. of } \\
\text { brake } \\
\text { application }\end{array}$ \\
\hline Burnish & 65 & 0.35 & $120^{\circ} \mathrm{C}$ & Off & 200 \\
\hline \multicolumn{6}{|l|}{ Effectiveness } \\
\hline Pre-effect & 50 & 0.3 & $80^{\circ} \mathrm{C}$ & Off & 10 \\
\hline \multirow[t]{3}{*}{ Effectiveness-I } & 50 & $0.1-0.8$ & $80^{\circ} \mathrm{C}$ & Off & $24^{\mathrm{a}}$ \\
\hline & 80 & $0.1-0.8$ & $80{ }^{\circ} \mathrm{C}$ & Off & $24^{\mathrm{a}}$ \\
\hline & 100 & $0.1-0.8$ & $80{ }^{\circ} \mathrm{C}$ & Off & $24^{\mathrm{a}}$ \\
\hline Re-burnish-I & 65 & 0.35 & $120^{\circ} \mathrm{C}$ & Off & 35 \\
\hline $\begin{array}{l}\text { Emergency } \\
\text { brake test }\end{array}$ & 80 & $0.1-0.25$ & $80^{\circ} \mathrm{C}$ & Off & 8 \\
\hline \multicolumn{6}{|l|}{$\begin{array}{l}\text { Fade\& } \\
\text { recovery-I }\end{array}$} \\
\hline Base line check & 50 & 0.3 & $80{ }^{\circ} \mathrm{C}$ & Off & 3 \\
\hline Fade-I & 80 & 0.45 & $\begin{array}{l}60{ }^{\circ} \mathrm{C} \\
\text { (for I } \\
\text { brake) }\end{array}$ & Off & 10 \\
\hline Recovery-I & 50 & 0.3 & $80{ }^{\circ} \mathrm{C}$ & On & 12 \\
\hline
\end{tabular}

\begin{tabular}{|c|c|c|c|c|c|}
\hline \multicolumn{6}{|c|}{ (Continued) } \\
\hline Description & $\begin{array}{l}\text { Speed } \\
(\mathrm{kmph})\end{array}$ & $\begin{array}{l}\text { Decele- } \\
\text { ration }(g)\end{array}$ & $\begin{array}{c}\text { Initial } \\
\text { temperture } \\
\left({ }^{\circ} \mathrm{C}\right)\end{array}$ & $\begin{array}{c}\text { Air } \\
\text { bower } \\
\text { condition a }\end{array}$ & $\begin{array}{l}\text { No. of } \\
\text { brake } \\
\text { pplication }\end{array}$ \\
\hline Re-burnish-II & 65 & 0.35 & $120^{\circ} \mathrm{C}$ & Off & 35 \\
\hline \multicolumn{6}{|l|}{$\begin{array}{l}\text { Fade\& } \\
\text { recovery-II }\end{array}$} \\
\hline Base line check & 50 & 0.3 & $80{ }^{\circ} \mathrm{C}$ & Off & 3 \\
\hline Fade-II & 80 & 0.45 & $\begin{array}{c}60{ }^{\circ} \mathrm{C} \\
\text { (for I } \\
\text { brake) }\end{array}$ & Off & 15 \\
\hline Recovery-II & 50 & 0.3 & $80^{\circ} \mathrm{C}$ & On & 12 \\
\hline
\end{tabular}

${ }^{\mathrm{a}}$ Three brake applications at each deceleration value.

\section{Appendix C}

DI water droplets on surfaces during contact angle measurement.
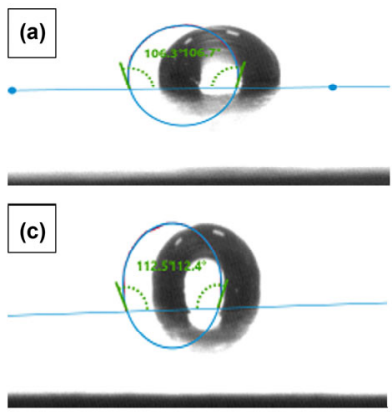

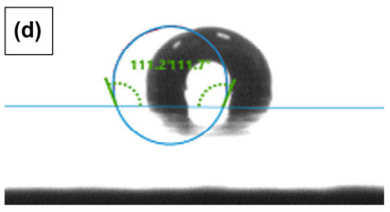

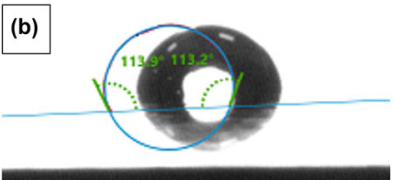

Fig. A1 Contact angle measurement of virgin and worn brakedisc with DI water. (a) Virgin brake-disc, (b-d) worn brake-discs of $A_{t}, A_{u}$, and $A_{0}$, respectively.
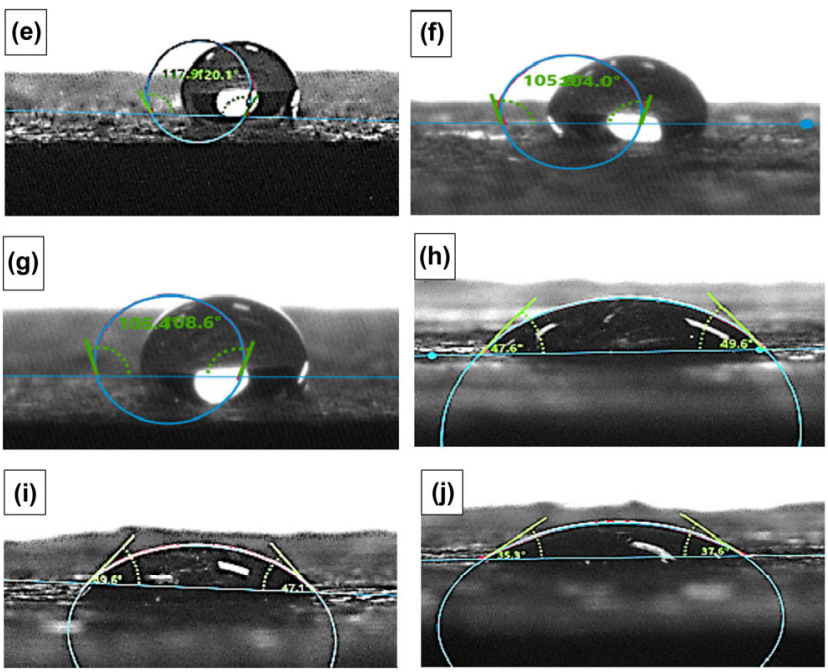

Fig. A2 Contact angle measurement of virgin and worn brakepads with DI water. (e-g) Virgin brake-pads $A_{0}, A_{u}$, and $A_{t}$, respectively; ( $h-j)$ worn brake-pad of $A_{0}, A_{u}$, and $A_{t}$, respectively. 
Open Access This article is licensed under a Creative Commons Attribution 4.0 International License, which permits use, sharing, adaptation, distribution and reproduction in any medium or format, as long as you give appropriate credit to the original author(s) and the source, provide a link to the Creative Commons licence, and indicate if changes were made.

The images or other third party material in this article are included in the article's Creative Commons licence, unless indicated otherwise in a credit line to the material. If material is not included in the article's Creative Commons licence and your intended use is not permitted by statutory regulation or exceeds the permitted use, you will need to obtain permission directly from the copyright holder.

To view a copy of this licence, visit http://creativecommons.org/licenses/by/4.0/.

\section{References}

[1] Bijwe J. Composites as friction materials: Recent developments in non-asbestos fiber reinforced friction materials-A review. Polym Compos 18(3): 378-396 (1997)

[2] Chan D, Stachowiak G W. Review of automotive brake friction materials. Proc Inst Mech Eng Part D J Automob Eng 218(D9): 953-966 (2004)

[3] Longley J W, Gardner R. Some Compositional Effects in the Static and Dynamic Properties of Commercial Vehicle Disk Brakes. ImechE C453/88 31-38 (1988).

[4] Jang $\mathrm{H}$, Kim S J. The effects of antimony trisulfide $\left(\mathrm{Sb}_{2} \mathrm{~S}_{3}\right)$ and zirconium silicate $\left(\mathrm{ZrSiO}_{4}\right)$ in the automotive brake friction material on friction characteristics. Wear 239(2): 229-236 (2000)

[5] Handa $\mathrm{Y}$, Kato T. Effects of $\mathrm{Cu}$ powder, $\mathrm{BaSO}_{4}$ and cashew dust on the wear and friction characteristics of automotive brake pads. Tribol Trans 39(2): 346-353 (1996)

[6] Trezona R I, Allsopp D N, Hutchings I M. Transitions between two-body and three-body abrasive wear: influence of test conditions in the microscale abrasive wear test. Wear 225: 205-214 (1999)

[7] Zum Gahr K H. Wear by hard particles. Tribol Int 31(10): 587-596 (1998)

[8] Dwyer-Joyce R S, Sayles R S, Ioannides E. An investigation into the mechanisms of closed three-body abrasive wear. Wear 175(1-2): 133-142 (1994)
[9] Gåhlin R, Jacobson S. The particle size effect in abrasion studied by controlled abrasive surfaces. Wear 224(1): 118-125 (1999)

[10] Kelly D A, Hutchings I M. A new method for measurement of particle abrasivity. Wear 250: 76-80 (2001)

[11] Matějka V, Lu Y F, Jiao L, Huang L,Martynkova G S, Tomasek V. Effects of silicon carbide particle sizes on friction-wear properties of friction composites designed for car brake lining applications. Tribol Int 43(1-2): 144-151 (2010)

[12] Rajan B S, Balaji M A S, Saravanakumar S S. Effect of chemical treatment and fiber loading on physico-mechanical properties of Prosopis juliflora fiber reinforced hybrid friction composite. Mater Res Express 6(3): 035302 (2018)

[13] Rajan B S, Balaji M A S, Noorani A B M A. Effect of silane surface treatment on the physico-mechanical properties of shell powder reinforced epoxy modified phenolic friction composite. Mater Res Express 6(6): 065315 (2019)

[14] Basak R, Choudhury P L, Pandey K M. Effect of temperature variation on surface treatment of short jute fiber-reinforced epoxy composites. Mater Today Proc 5(1): 1271-1277 (2018)

[15] Yang Y C, Jeong S B, Kim B G, Yoon P R. Examination of dispersive properties of alumina treated with silane coupling agents, by using inverse gas chromatography. Powder Technol 191(1-2): 117-121 (2009)

[16] Lee C H, Park S H, Chung W, Kim J Y, Kim S H. Preparation and characterization of surface modified silica nanoparticles with organo-silane compounds. Colloids Surfaces A Physicochem Eng Asp 384(1-3): 318-322 (2011)

[17] Abdelmouleh M, Boufi S, Belgacem M N, Dufresne A. Short natural-fibre reinforced polyethylene and natural rubber composites: effect of silane coupling agents and fibres loading. Compos Sci Technol 67(7-8): 1627-1639 (2007)

[18] Kumar M, Bijwe J. NAO friction materials with various metal powders: Tribological evaluation on full-scale inertia dynamometer. Wear 269(11-12): 826-837 (2010)

[19] Mahale V, Bijwe J, Sinha S. A step towards replacing copper in brake-pads by using stainless steel swarf. Wear 424: 133-142 (2019)

[20] Aranganathan N, Bijwe J. Development of copper-free eco-friendly brake-friction material using novel ingredients. Wear 352: 79-91 (2016) 


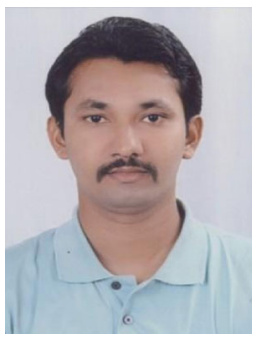

Vanvirsinh CHAUHAN. He received his master degree (M.E.) in mechanical engineering in 2008 from Gujarat University, Gujarat, India. He joined the State Government Engineering College as an assistant

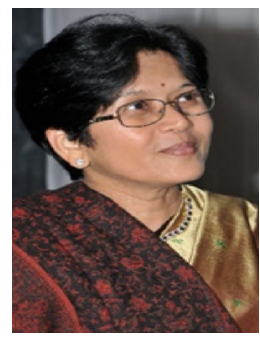

Jayashree BIJWE. She did her Ph.D. from Indian Institute of Technology, Delhi (IITD), India, and is working as a professor in IITD since last 25

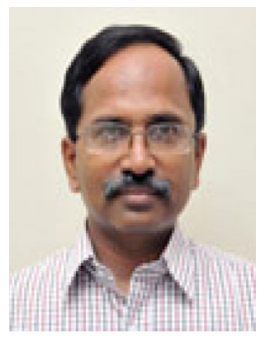

Ashish DARPE. He is a postgraduate in machine design from Visvesvaraya National Institute of Technology, Nagpur, India. He did his doctoral research at the Indian Institute of Technology Delhi in the professor at Gujarat Technological University from 2011. Currently, he is pursuing Ph.D. from Indian Institute of Technology (IIT), Delhi, India. His research interests include friction materials, tribology, and noise-vibration.

years. Her research areas cover tribology of polymer composites (dry bearings and materials, NAO Brakepads and friction materials, and adhesives) and additives for oils and greases.

area of rotor dynamics. He is currently a professor in the Department of Mechanical Engineering, IIT Delhi. His research interests include $\mathrm{NVH}$, rotor dynamics, condition monitoring, and vibration and noise control. 